\section{Common Proteins Located in Pigeon, Budgerigar, and Hen Droppings Related to Bird Fancier's Lung}

Rouzet $\mathrm{A}^{1}$, Valot $\mathrm{B}^{1}$, Reboux $\mathrm{G}^{1,2}$, Millon $\mathrm{L}^{1,2}$, Roussel $\mathrm{S}^{1,3}$

${ }^{1}$ UMR 6249 Chrono-Environment, University of Bourgogne-

Franche-Comté, Besançon, France

${ }^{2}$ Parasitology-Mycology Department, University Hospital of

Besançon, Besancon, France

${ }^{3}$ Biomedical Department, University Hospital of Besançon, Besancon, France

J Investig Allergol Clin Immunol 2018; Vol. 28(3): 182-184 doi: 10.18176/jiaci.0223

Key words: Bird fancier's lung. Cross-reactions. Shotgun. Mass spectrometry. Bird droppings.

Palabras clave: Pulmón de los criadores de pájaros. Reacciones cruzadas. Escopeta. Espectometría de masas. Excrementos de aves.

Hypersensitivity pneumonitis (HP) is an immunemediated lung disease that develops after inhalation of various environmental antigens in sensitized individuals. Bird fancier's lung $(\mathrm{BFL})$ is one of the most common forms of HP and is caused by exposure to avian antigens located in droppings, feathers, and bloom (white powder that coats the feathers) [1]. Diagnosis is based on a combination of clinical, radiological, functional, and biological criteria, including the presence of serum antibodies against the causative antigens [2]. Standard serological techniques are performed using crude or purified antigens (commercial or in-house) from bird droppings, feathers, and sera.

Cross-reactions between various kinds of birds are frequently observed in serological analyses $[3,4]$. Most of the time, patients exposed to pigeons also react positively to budgerigar antigens [5]. However, the proteins involved in these reactions have rarely been investigated and are therefore poorly characterized. The objectives of this study were to compare proteins from pigeon, budgerigar, and hen droppings and to investigate the antigens involved in cross-reactions.

Droppings were collected at breeding farms located in the Franche-Comté region. A shotgun proteomics-based approach with mass spectrometry (LC-MS/MS) was used to identify the major proteins from pigeon, budgerigar, and hen droppings, as previously described [6]. Proteins were identified with X! Tandem Pipeline (version 2015.04.01.1 [7]) using the following protein databases: Columba livia (http:// www.ncbi.nlm.nih.gov/protein/?term=txid8932[Organism:n oexp]), Melopsittacus undulatus (http://www.ncbi.nlm.nih. gov/genome/?term=Melopsittacus\%20undulatus), and Gallus gallus proteome (http://www.uniprot.org).
The shotgun approach identified 156 proteins from pigeon droppings, 119 from budgerigar droppings, and 86 from hen droppings. The clustering of orthologous proteins with at least $60 \%$ identity (cd-hit [8]) enabled the constitution of 128 protein groups with different functions. Proteins specific to the droppings of each species represented $38.3 \%$ of the total proteins compared with $61.7 \%$ of proteins that were common to at least 2 birds. The results showed that more proteins were common to the droppings of different species of birds than specific to the droppings of 1 bird species: 24\% (23/97) of the proteins of pigeon droppings were specific, as were $21 \%$ (18/86) for budgerigar and 15\% (8/55) for hen. These proteins were involved in the immune system, the cytoskeleton, and metabolism (lipid, carbohydrate, and protein).

Greater similarity was observed for pigeon and budgerigar droppings, with $52.5 \%$ common protein functions. Hen droppings shared proteins with pigeon and budgerigar droppings ( $38 \%$ and $34 \%$, respectively).

The results of these analyses showed the presence of a group of 31 proteins common to the droppings of the 3 bird species ( $24 \%$ of the total proteins). These proteins functioned as immunoglobulin, carboxypeptidase, annexin, chymotrypsin, serum albumin, mucin, meprin A, pancreatic lipase, pancreatic $\alpha$-amylase, peptidase, endonuclease, and actin.

In a previous study, we identified 14 antigenic proteins from pigeon droppings involved in BFL [6]. Among the 31 proteins common to the droppings of the 3 species of birds, we detected 10 proteins that were orthologous to the antigenic pigeon proteins involved in BFL. Most of the antigenic proteins were abundant in pigeon droppings [6]. Three others were only detected in pigeon and hen droppings and were shown to be the Ig heavy chain VIII region VH26, chymotrypsinogen 2, and proproteinase E. Local alignments between the amino acid sequences of these proteins were achieved using BLASTp tools. The results of these analyses are shown in the Table.

The 33 alignments indicated a minimum coverage of $73 \%$, a percentage of identity that varies from $62 \%$ to $89 \%$, and a similarity percentage that varies from $76 \%$ to $95 \%$. Meprin A, pancreatic $\alpha$-amylase, and serum albumin were the most conserved proteins among the droppings of these 3 species, with both identity and coverage percentages, respectively, above $80 \%$ and $95 \%$. The alignment of the amino acid sequences of these proteins showed that they were relatively conserved from one species to another. Consistent with these results, chicken, duck, and turkey serum albumins have been shown to have high sequence identities (79.6-84.2\%) and similarities (85-90.2\%) relative to pigeon serum albumin [9].

These conserved amino acid regions may correspond to sequential antibody-binding sites. Furthermore, we previously showed that the pigeon immunoglobulin lambda-like polypeptide 1 (IGLL1) protein was involved in cross-antigenic reactions. In fact, this protein, which is common to pigeon, 
Table. Alignment of Amino Acid Sequences of Budgerigar, Hen, and Pigeon Proteins

\begin{tabular}{|c|c|c|c|}
\hline $\begin{array}{l}\text { Antigenic Proteins } \\
\text { of Pigeon Droppings } \\
\text { (Accession Number) }\end{array}$ & $\begin{array}{l}\text { Identity of Orthologous Proteins } \\
\text { in the Budgerigar Droppings } \\
\text { Alignment Budgerigar/Pigeon }\end{array}$ & $\begin{array}{l}\text { Identity of Orthologous Proteins } \\
\text { in the Hen Droppings } \\
\text { Alignment Hen/Pigeon }\end{array}$ & $\begin{array}{l}\text { Alignment } \\
\text { Budgerigar/Hen }\end{array}$ \\
\hline $\begin{array}{l}\text { IgGFc-binding protein-like, } \\
\text { partial (XP_013226161) }\end{array}$ & $\begin{array}{l}\text { IgGFc-binding protein-like } \\
\text { (XP 005141227) } \\
\text { ID: } 84 \% \text {, SIM } 88 \%(99 \%)\end{array}$ & $\begin{array}{l}\text { Uncharacterized protein FCGBP } \\
\text { (XP 015146991) } \\
\text { ID: } 79 \% \text {, SIM: } 85 \%(97 \%)\end{array}$ & $\begin{array}{l}\text { ID: } 70 \% \\
\text { SIM: } 79 \%(94 \%)\end{array}$ \\
\hline $\begin{array}{l}\text { Ig heavy chain V-III } \\
\text { region VH26, } \\
\text { partial (EMC } 81137 \text { ) }\end{array}$ & No orthologous proteins & $\begin{array}{l}\text { Immunoglobulin Y heavy chain } \\
\text { variable region, partial (ADF29959) } \\
\text { ID: } 75 \% \text {, SIM: } 82 \%(93 \%)\end{array}$ & $\begin{array}{l}\text { No orthologous } \\
\text { proteins in } \\
\text { budgerigar }\end{array}$ \\
\hline $\begin{array}{l}\text { Meprin A subunit alpha } \\
\text { (EMC80533) }\end{array}$ & $\begin{array}{l}\text { Meprin A subunit alpha } \\
\text { (XP 012983842) } \\
\text { ID: } 85 \% \text {, SIM : } 92 \%(99 \%)\end{array}$ & $\begin{array}{l}\text { Meprin A subunit alpha precursor } \\
\text { (NP_001264650) } \\
\text { ID : } 83 \% \text {, SIM : } 90 \%(97 \%)\end{array}$ & $\begin{array}{l}\text { ID: } 81 \% \\
\text { SIM: } 89 \%(97 \%)\end{array}$ \\
\hline $\begin{array}{l}\text { Pancreatic alpha-amylase } \\
\text { (EMC78994) }\end{array}$ & $\begin{array}{l}\text { Pancreatic alpha-amylase } \\
\text { (XP 005141024) } \\
\text { ID: } 89 \% \text {, SIM: } 95 \%(100 \%)\end{array}$ & $\begin{array}{l}\text { Pancreatic alpha-amylase precursor } \\
\text { (NP_001001473) } \\
\text { ID: } 88 \% \text {, SIM: } 94 \%(100 \%)\end{array}$ & $\begin{array}{l}\text { ID: } 89 \% \\
\text { SIM: } 94 \%(100 \%)\end{array}$ \\
\hline $\begin{array}{l}\text { Carboxypeptidase A1 } \\
\text { (EMC89479) }\end{array}$ & $\begin{array}{l}\text { Carboxypeptidase A1-like } \\
\text { (XP_012985652) } \\
\text { ID: 66\%, SIM: } 82 \%(88 \%)\end{array}$ & $\begin{array}{l}\text { Carboxypeptidase A1 preproprotein } \\
\text { (NP -989915) } \\
\text { ID: } 80 \% \text {, SIM: } 90 \%(96 \%)\end{array}$ & $\begin{array}{l}\text { ID: } 65 \% \text {, } \\
\text { SIM: } 79 \%(98 \%)\end{array}$ \\
\hline $\begin{array}{l}\text { Serum albumin } \\
\text { (EMC85061) }\end{array}$ & $\begin{array}{l}\text { Serum albumin } \\
\text { (XP_005144193) } \\
\text { ID: } 84 \% \text {, SIM: } 92 \%(99 \%)\end{array}$ & $\begin{array}{l}\text { Serum albumin } \\
\text { (NP } 990592) \\
\text { ID: } 81 \% \text {, SIM: } 88 \%(100 \%)\end{array}$ & $\begin{array}{l}\text { ID: } 81 \% \\
\text { SIM: } 90 \%(99 \%)\end{array}$ \\
\hline $\begin{array}{l}\text { Chymotrypsin-C } \\
\text { (XP_005508006) }\end{array}$ & $\begin{array}{l}\text { Chymotrypsin-C } \\
\text { (XP 005145536) } \\
\text { ID: } 78 \% \text {, SIM: } 87 \%(98 \%)\end{array}$ & $\begin{array}{l}\text { Chymotrypsin-C } \\
\text { (NP } 001264846) \\
\text { ID: } 78 \% \text {, SIM: } 87 \%(100 \%)\end{array}$ & $\begin{array}{l}\text { ID: } 74 \% \text {, } \\
\text { SIM: } 84 \%(95 \%)\end{array}$ \\
\hline $\begin{array}{l}\text { Ig lambda chain V-1 region, } \\
\text { partial (EMC88596) }\end{array}$ & $\begin{array}{l}\text { Immunoglobulin superfamily } \\
\text { DCC subclass member 3-like } \\
\text { (XP } 012984140) \\
\text { ID: } 73 \% \text {, SIM: } 77 \%(73 \%)\end{array}$ & $\begin{array}{l}\text { Immunoglobulin lambda light } \\
\text { chain, partial (BAB71871) } \\
\text { ID: } 81 \% \text {, SIM: } 87 \%(100 \%)\end{array}$ & $\begin{array}{l}\text { ID: } 76 \% \text {, } \\
\text { SIM: } 78 \%(90 \%)\end{array}$ \\
\hline $\begin{array}{l}\text { Pancreatic lipase-related } \\
\text { protein } 1 \text { (EMC84847) }\end{array}$ & $\begin{array}{l}\text { Pancreatic triacylglycerol } \\
\text { lipase-like (XP 012985881) } \\
\text { ID: } 76 \% \text {, SIM: } 88 \%(100 \%)\end{array}$ & $\begin{array}{l}\text { Pancreatic triacylglycerol lipase } \\
\text { precursor (NP_001264311) } \\
\text { ID: } 72 \% \text {, SIM: } 84 \%(100 \%)\end{array}$ & $\begin{array}{l}\text { ID: } 78 \% \text {, } \\
\text { SIM: } 86 \%(100 \%)\end{array}$ \\
\hline $\begin{array}{l}\text { Chymotrypsinogen } 2 \\
\text { (EMC89394) }\end{array}$ & No orthologous proteins & $\begin{array}{l}\text { Chymotrypsinogen 2-like } \\
\text { (NP 001264565) } \\
\text { ID: } 79 \% \text {, SIM: } 85 \%(95 \%)\end{array}$ & $\begin{array}{l}\text { No orthologous } \\
\text { proteins in budgerigar }\end{array}$ \\
\hline $\begin{array}{l}\text { Polymeric immunoglobulin } \\
\text { receptor (XP_005510447) }\end{array}$ & $\begin{array}{l}\text { Polymeric immunoglobulin } \\
\text { receptor (XP 005143290) } \\
\text { ID: } 75 \% \text {, SIM: } 84 \%(88 \%)\end{array}$ & $\begin{array}{l}\text { Polymeric immunoglobulin } \\
\text { receptor (NP_001038109) } \\
\text { ID: } 62 \% \text {, SIM: } 78 \%(100 \%)\end{array}$ & $\begin{array}{l}\text { ID: } 62 \% \\
\text { SIM: } 76 \%(100 \%)\end{array}$ \\
\hline $\begin{array}{l}\text { Immunoglobulin lambda-like } \\
\text { polypeptide } 1 \text { (XP_005503921) }\end{array}$ & $\begin{array}{l}\text { Immunoglobulin lambda-like } \\
\text { polypeptide } 1(\mathrm{XP} 012984154) \\
\text { ID: } 63 \% \text {, SIM: } 76 \%(94 \%)\end{array}$ & $\begin{array}{l}\text { Ig light chain (AAA48918) } \\
\text { ID: } 68 \% \text {, SIM: } 78 \%(99 \%)\end{array}$ & $\begin{array}{l}\text { ID: } 65 \% \text {, } \\
\text { SIM: } 76 \%(99 \%)\end{array}$ \\
\hline $\begin{array}{l}\text { Proproteinase E } \\
\left(\mathrm{XP} \_005514568\right)\end{array}$ & No orthologous proteins & $\begin{array}{l}\text { Chymotrypsin-like elastase } \\
\text { family member 3B (XP 015152723) } \\
\text { ID: } 73 \% \text {, SIM: } 80 \%(95 \%)\end{array}$ & $\begin{array}{l}\text { No orthologous } \\
\text { proteins in budgerigar }\end{array}$ \\
\hline
\end{tabular}

Abbreviations: ID, identity; SIM, similarity.

${ }^{a}$ Alignments were conducted using BLASTp tools, which are freely available at https://blast.ncbi.nlm.nih.gov/Blast.cgi?PAGE=Proteins.

budgerigar, and hen droppings, makes it possible to diagnose patients exposed to pigeon, budgerigar, and hen. Since the recombinant IGLL1 protein is produced under denaturing conditions, the IgG antibodies of BFL patients recognize sequential epitopes of this protein.

Thus, these results may help to increase our understanding of the cross-antigenic reactions detected in the serological analyses applied in the diagnosis of BFL. In accordance with our study, Sennekamp et al [4] showed that serum albumin, globulins, and avian intestinal antigens were responsible for antigenic cross-reactions in $60 \%$ of the breeders. Previously, we used antigens from pigeon, budgerigar, and hen droppings to detect the specific immunogenic proteins of each species [10]. Only one $68-\mathrm{kDa}$ immunogenic protein was visualized in 
both pigeon and budgerigar droppings, while proteins of 200 , $175,140,100$, and $35 \mathrm{kDa}$ were detected as specific in 1 bird species. Although only 1 common immunoreactive protein was detected with western blot assay, our molecular approach showed the presence of several antigenic pigeon proteins in budgerigar and hen droppings.

In conclusion, this study enabled us to provide a list of proteins common to 3 bird species. In order to further investigate this approach, the proteins should be produced by genetic engineering (recombinant antigens) for each species to validate their cross-antigenicity by ELISA IgG test using a cohort comprising BFL patients, asymptomatic exposed breeders, and nonexposed individuals. The proteins we identified proved valuable for improving and simplifying the serodiagnosis of BFL, because they are effective for exposure to pigeons, budgerigars, and hens and will increase our knowledge and understanding of the mechanisms of the disease. Animal studies examining inflammatory and immune mechanisms will be necessary to identify which of these common proteins are capable of generating pulmonary granulomas and which are useful exclusively as biomarkers for detection of disease.

\section{Acknowledgments}

The authors are grateful to Pamela Albert for editorial assistance. We thank the PAPPSO (Plateforme d'Analyse Protéomique de Paris Sud Ouest) for performing the LC-MS/ MS analysis.

\section{Funding}

This study was funded by Besançon University Hospital (API3A: HYPERSENS: N²015-A01803-46).

\section{Conflicts of Interest}

The authors declare that they have no conflicts of interest.

\section{References}

1. McSharry C, Anderson K, Boyd G. A review of antigen diversity causing lung disease among pigeon breeders. Clin Exper Allergy. 2000;30(9):1221-9.

2. Lacasse Y, Selman M, Costabel U, Dalphin J-C, Ando M, Morell $F$, et al. Clinical diagnosis of hypersensitivity pneumonitis. Am J Respir Crit Care Med. 2003;168(8):952-8

3. Kokkarinen J, Tukiainen H, Seppa A, Terho EO. Hypersensitivity pneumonitis due to native birds in a bird ringer. Chest. 1994;106(4):1269-71.

4. Sennekamp J, Lange G, Nerger K, Berdel D, Meier-Sydow J. Human antibodies against antigens of the sparrow, blackbird, weaver finch, canary, budgerigar, pigeon and hen using the indirect immunofluorescent technique. Clin Allergy. 1981;11(4):375-84.

5. Mashio K, Fukushima Y, Oomi F, Umetsu T, Yoshida N, Ikeda $\mathrm{N}$, et al. Involvement of Bird-related IgG Antibodies in Interstitial Pneumonia. Dokkyo journal of medical sciences. 2013;40(1):39-46.

6. Rouzet A, Reboux G, Dalphin J-C, Gondouin A, De Vuyst P, Balliau T, et al. An immunoproteomic approach revealed antigenic proteins enhancing serodiagnosis performance of bird fancier's lung. J Immunol Methods. 2017;450:58-65.

7. Langella $\mathrm{O}$, Valot $B$, Balliau T, Blein-Nicolas M, Bonhomme L, Zivy M. X! TandemPipeline: a tool to manage sequence redundancy for protein inference and phosphosite identification. J Proteome Res. 2016;16(2):494-503.

8. Li W, Godzik A. Cd-hit: a fast program for clustering and comparing large sets of protein or nucleotide sequences. Bioinformatics. 2006;22(13):1658-9.

9. Chruszcz M, Mikolajczak K, Mank N, Majorek KA, Porebski PJ, Minor W. Serum albumins-Unusual allergens. Biochim Biophys Acta. 2013;1830(12):5375-81.

10. Rouzet A, Reboux G, Rognon B, Barrera C, De Vuyst P, Dalphin $\mathrm{J}-\mathrm{C}$, et al. Immunogenic proteins specific to different bird species in bird fancier's lung. J Toxicol Environ Health $A$. 2014;77(12):724-30

Manuscript received September 19, 2017; accepted for publication December 20, 2017.

Adeline Rouzet

UMR 6249 Chrono-Environment University of Bourgogne-Franche-Comté 19 rue Ambroise Paré 25030 Besançon, France E-mail: adeline.rouzet@univ-fcomte.fr 